\title{
Chronic Obstructive Pulmonary Disease and Associated Factors in Arba Minch Health and Demographic Surveillance Site, 2020
}

\author{
Eskezyiaw Agedew $\mathbb{D}^{\prime}$ \\ Belay Boda $\mathbb{D}^{2}$ \\ Tesfaye Kanko (iD) ${ }^{2}$ \\ Wubshet Estifanos (iD) ${ }^{3}$ \\ Tamiru Shibiru (1D) \\ 'Department of Public Health, College of \\ Health Sciences, Debre Markos \\ University, Debre Markos, Ethiopia; \\ ${ }^{2}$ Department of Biomedical Sciences, \\ College of Medicine and Health Sciences, \\ Arba Minch University, Arba Minch, \\ Ethiopia; ${ }^{3}$ School of Nursing, College of \\ Medicine and Health Sciences, Arba \\ Minch University, Arba Minch, Ethiopia; \\ ${ }^{4}$ School of Medicine, College of Medicine \\ and Health Sciences, Arba Minch \\ University, Arba Minch, Ethiopia
}

Introduction: Chronic obstructive pulmonary disease (COPD) is a worldwide public health problem. The Global Initiative for Chronic Obstructive Lung Disease (GOLD) defines COPD as a common, preventable and treatable disease characterized by progressive airflow limitation. Nowadays, COPD has become the third leading cause of death and fourth cause of mortality in the world.

Objective: To assess chronic obstructive pulmonary disease and associated factors in Arba Minch - Health and Demographic Surveillance Site (AMU-HDSS) of Arba Minch University.

Methods: A community-based cross-sectional study was conducted in AMU-HDSS among 615 individuals who were $>15$ years of age. Study participants were selected randomly by the lottery method. Spirometer device was used to measure lung function. Binary logistic regression analysis was computed to assess the crude association between dependent and independent variables. Finally, variables which showed association in binary logistic regression analysis and have a $P$-value less than 0.3 were entered into multivariable logistic regression model to identify significant factors.

Results: The prevalence of spirometry diagnosed COPD was 10.6\%. Highland residence showed higher proportion of COPD case which accounts $63.8 \%$ compared to $36.2 \%$ in lowland residence. Study participants who were in advanced age $>41$ years adjusted odd ratio (AOR) $3.65(1.83,7.28)$, living in highland area AOR $1.71(1,2.92)$, those who are elementary education level $2.45(1.13,5.28)$, who had no separate house for domestic animals AOR 2.84 (1.38, 5.85), having house which had no windows AOR 3.05 (5.79, 1.12) and living in traditional hut (tukulu), AOR $5.92(1.19,29.42)$ were significantly associated with chronic obstructive pulmonary disease in the study area.

Conclusion and Recommendation: Chronic obstructive pulmonary disease was one of respiratory illnesses in people who live in highland and traditional house lacking windows for air circulation. Improving housing condition of traditional hut by constructing window, separating domestic animals house from humans and minimizing animal dung smoke exposure is necessary to reduce the respiratory illness.

Keywords: spirometer, housing condition, air pollution, Arba Minch University

\section{Introduction}

Chronic obstructive pulmonary disease (COPD) is characterized by lower airway inflammation and damage that impairs airflow. COPD is the fourth leading cause of death worldwide resulting in chronic diffuse irreversible airflow obstruction mainly in small airways. It also defined as a low ratio of forced expiratory volume in
Correspondence: Belay Boda PO Box: 021

Tel +25I 916278453

$\mathrm{Fax}+25146881-4264$

Email belaylove2002@gmail.com 
one second $\left(\mathrm{FEV}_{1}\right)$ to forced vital capacity $(\mathrm{FVC}){ }^{1,2}$ It is a growing cause of morbidity, disability, and mortality both in developed and developing countries that can be related to environmental exposures, smoking and respiratory infectious diseases. ${ }^{3,4}$

The main causes of COPD in high-income countries are tobacco smoke and occupational exposure, but in lowincome and middle-income countries use of biomass fuel (wood, dung, crop residues, and charcoal) for cooking and domestic heating is a major cause of COPD and childhood respiratory infections. ${ }^{5,6}$ Chronic obstructive pulmonary disease (COPD), once regarded as a disease of highincome countries, is now recognized as common in lowincome and middle-income countries. ${ }^{1,5}$ The World Health Organization (WHO) has estimated that about 65 million people suffer from moderate to severe COPD worldwide. A striking issue with COPD is that the condition is often underestimated by the patient, largely under diagnosed and undertreated in African countries. ${ }^{7}$

Previously published studies evaluating the prevalence of COPD have provided a range of estimates across different countries. The prevalence of COPD diagnosed by spirometry ranged from 37 per 1000 (United Arab Emirates) to 240 per 1000 (in Netherlands). ${ }^{8}$ Low- and middle-income countries share the greatest proportion of COPD worldwide. More than half of those with COPD live in low and middle income countries. ${ }^{2}$ It has a major impact on health-care expenditure and can impose a substantial economic burden on patients and healthcare service providers. In addition, COPD has a major negative impact on the daily lives of patients, as it impairs individual well-being, functional status and work production. ${ }^{9}$ One of the major affects of COPD is that it causes high economic impact. The estimated total annual cost of COPD for 2010 was $\$ 49.9$ billion. $^{8}$

According to WHO, around three billion people in the world still cook and heat their homes using dirty solid fuels (such as waste wood, charcoal, coal, dung, crop wastes) on open fireplaces, cooking stoves, which generates a large amount of air pollutants (such as $\mathrm{SO}_{2}, \mathrm{NO}_{2}$, $\mathrm{CO}$, and $\mathrm{PM}$ ). These air pollutants may accumulate in the indoor environment if not well ventilated, which seriously affects the health of the inhabitants..$^{10,11}$

The Ethiopian government gives advice on control of common communicable respiratory diseases like tuberculosis and pneumonia as one of the primary health-care services, but chronic non-communicable respiratory disease has not been given due attention in spite of a large number of people suffering from COPD and asthma both in urban and rural areas. The problem of COPD alarmingly increasing, there is no planned public health intervention at country level due to lack sufficient evidence on prevalence and contributing factors for COPD in Ethiopia. The current study would provide valuable information for the community at large, decision makers, health-care planners, evaluators, and medical practitioners for promoting better health, quality of life, and the prevention of disability in from COPD.

\section{Materials and Methods Study Setting and Design}

A community-based cross-sectional study was conducted from August 2019 to February 2020 in the Arba Minch demographic and health surveillance system sites (AMHDSS). Arba Minch, the capital city of Gamo zone, is found at an altitude of $130 \mathrm{~m}$ above sea level with the average temperature of $29^{\circ} \mathrm{C}$. Based on the 2014 data, this district has a total population of 164,529 , of whom 82,199 are men and 82,330 women. Arba Minch Zuria district has a total of 31 kebeles with three different climatic zones, highland, midland and lowland, among which nine kebeles are under HDSS. According to HDSS report, there are total populations of 74,157 in the surveillance site.

\section{Population}

Randomly selected individuals who are $>15$ years old and live in AM-HDSS during the study period are the study population.

\section{Inclusion and Exclusion Criteria}

Individuals who lived in the HDSS for at least six months were included and those who are known asthmatic and tuberculosis cases were excluded from the study.

\section{Sample Size Determination}

The sample size for prevalence of COPD is determined by using single population proportion formula by taking prevalence $(\mathrm{P})$ of COPD in Uganda 16.2\% [12], 95\% confidence level (Z) and margin of error (D) $3 \%$.

$$
\mathrm{N}=\frac{\mathrm{Z}^{2} \mathrm{PQ}}{D^{2}}=\frac{1.96 * 1.96 * 0.162 * 0.84}{0.03^{2}}=580
$$

By adding 10\% non-response rate the final sample size for the study 638 (the sample size for factors affecting COPD 
were considered after calculating by using Epi Info ${ }^{\mathrm{TM}}$ version 7).

\section{Sampling Technique}

First, from nine kebeles under HDSS three sites from highland and other three from lowland climatic zone were selected randomly by lottery methods. The sampling frame was prepared by taking a list of households from HDSS of Arba Minch University. Then sample sized was allocated proportionally based on the number of households in the selected HDSS site, finally the study sample was selected by simple random method and then house-to-house interviews and measurements were conducted.

\section{Study Variables}

Dependent variable: chronic obstructive pulmonary disease (yes, no).

Independent variables: sociodemographic characteristics (age, sex, religion, educational status, occupation, income), housing condition like number of rooms, number of windows and ventilation, smoking, indoor air pollution, biomass fuel utilization, and respiratory symptoms (cough, wheezing, shortness of breath).

\section{Operational Definition}

- Chronic obstructive pulmonary disease (COPD): it is a preventable and treatable disease state characterized by air flow limitation that is not fully reversible. The main criterion for COPD is a $\mathrm{FEV}_{1} / \mathrm{FVC}$ ratio $<70 \%$.

- FVC: The volume of air that can forcibly be blown out after maximum inspiration $(30,32)$.

- $\mathrm{FEV}_{1}$ : This is the speed of air forcibly expelled from the lungs in the first one second from maximal inspiration.

\section{Data Collection Tools and Procedure}

A structured pretested questionnaire was used for the collection of sociodemographic data, clinical manifestations related to COPD, housing conditions and other factors. Spirometer device was used in accordance with the American Thoracic Society and European Respiratory Society recommendations: at least three measurements were taken every five minutes. The final largest values for both forced vital capacity (FVC) and forced expiratory volume in one second $\left(\mathrm{FEV}_{1}\right)$ within
$150 \mathrm{~mL}$ or no more than $5 \%$ difference; the largest values for $\mathrm{FVC}$ and $\mathrm{FEV}_{1}$ were considered the best and used for analysis. Spirometer was calibrated every morning. The housing conditions data were also collected by using observational check list. Four experienced MSc physiologist and 12 clinical nurses were used for data collection.

\section{Data Quality Assurance}

To ensure data quality, two days training was given for data collectors on how to measure lung function status and interview study participants. Before actual data collection, pretest was done on $5 \%$ of the sample out of the study site of AM-HDSS. Frequent calibration of spirometer was undertaken before conducting the actual recording.

\section{Data Analysis}

Data were collected by an open data kit data collection application and transferred to SPSS version 20 for analysis. Data collected by spirometer were exported to computer for further analysis. Before the actual data analysis, the data were checked for its completeness, outliers and missing values by conducting univariate analysis. Descriptive statistics like cross tabulation were calculated to describe the study population in relation to relevant variables. Exploratory data analysis was done to check potential outliers and the normality distribution for continuous variables. Binary logistic regression analysis was conducted to assess the crude association between dependent and independent variables. Finally, variables which show association in binary logistic regression analysis and have a $P$-value less than 0.3 were entered into multivariable logistic regression model to identify significant factors. The significant factors was identified based on adjusted odds ratio (AOR) with $95 \%$ confidence level and $P \leq 0.05$.

\section{Ethical Consideration}

The study was conducted according to the Declaration of Helsinki as a statement of ethical principles for medical research involving human subjects. Ethical clearance was obtained from the institutional review committee of College of Medicine and Health Science, Arba Minch University. The study was conducted only by individuals with the appropriate ethics 
and scientific education, training and qualifications. The investigators had taken every precaution to protect the life, health, dignity, integrity, right to selfdetermination, privacy, and confidentiality of personal information of research subjects. During data collection, the purpose, method, anticipated benefits and potential risks of the study was clearly explained to the participants and informed written consent was obtained from each study participant. Finally, study participants with impaired respiratory function who have COPD and asthma were linked to the health facility for medical treatment.

\section{Results}

\section{Sociodemographic Characteristics}

The data were collected from 615 study participants with a $96.4 \%$ response rate. Among study participants $53.8 \%$ were male. The median age of the study participants were 38 years and $58 \%$ of the study participants were above 40 years. Regarding the educational status of study participants $69.4 \%$ had no formal education and $67.8 \%$ of them were farmers in their occupation. From all study participants $87.3 \%$ were married and $46.5 \%$ of households had a family size above six (Table 1).

\section{Housing Conditions}

Among 615 households included in the study, 58.7\% of houses were traditional hut (tukulu), 37.9\% were constructed from iron sheets and mud. Only $3.4 \%$ of house were constructed from iron sheets and cemented materials. Among the houses, $64.2 \%$ have only one room, $31.4 \%$ of them have 2-3 rooms and the rest have more than four rooms.

Regarding the number of windows and rooms, $84.55 \%$ houses constructed from iron sheets and cement materials have more than two rooms and $64.38 \%$ have more than three windows. In contrast from 361 traditional hut (tukulu) $347(96.12 \%)$ have no windows (Figure 1).

\section{Households Smoke Exposure, Ventilation and Illumination}

All households utilized biomass fuel as energy sources for food preparation. The common utilized biomass
Table I Sociodemographic Characteristics of Study Participants in AM-HDSS, Southern Ethiopia, 2020

\begin{tabular}{|c|c|c|c|}
\hline Variable & Variable Category & Frequency & Percent \\
\hline \multirow[t]{2}{*}{ Sex } & Male & 331 & 53.8 \\
\hline & Female & 284 & 46.2 \\
\hline \multirow[t]{4}{*}{ Age } & $<40$ & 357 & 58 \\
\hline & $4 I-50$ & 133 & 21.6 \\
\hline & $5 I-60$ & 73 & 11.9 \\
\hline & $>60$ & 52 & 8.5 \\
\hline \multirow{3}{*}{$\begin{array}{l}\text { Educational } \\
\text { status }\end{array}$} & No formal education & 427 & 69.4 \\
\hline & Elementary school & 46 & 7.5 \\
\hline & Secondary and above & 142 & 23.1 \\
\hline \multirow[t]{6}{*}{ Occupation } & Farmer & 417 & 67.8 \\
\hline & Housewife & 95 & 15.4 \\
\hline & Government worker & 21 & 3.4 \\
\hline & Merchant & 26 & 4.2 \\
\hline & Student & 26 & 4.2 \\
\hline & Other & 30 & 4.9 \\
\hline \multirow[t]{5}{*}{ Marital status } & Married & 537 & 87.3 \\
\hline & Single & 16 & 2.6 \\
\hline & Widowed & 5 & 0.8 \\
\hline & Separated & 7 & 1.1 \\
\hline & Divorce & 50 & 8.1 \\
\hline \multirow[t]{7}{*}{ Ethnicity } & Gamo & 517 & 84.1 \\
\hline & Gofa & 50 & 8.1 \\
\hline & Amhara & 4 & 0.7 \\
\hline & Wollayta & 4 & 0.7 \\
\hline & Oromo & 3 & 0.5 \\
\hline & Guraghe & 10 & 1.6 \\
\hline & Others & 27 & 4.4 \\
\hline \multirow[t]{3}{*}{ Religion } & Orthodox & 200 & 32.5 \\
\hline & Protestant & 406 & 66 \\
\hline & Other & 9 & 1.5 \\
\hline \multirow[t]{3}{*}{ Family size } & $1-2$ & 39 & 6.3 \\
\hline & $3-5$ & 290 & 47.2 \\
\hline & $\geq 6$ & 286 & 46.5 \\
\hline \multirow[t]{5}{*}{ Wealth index } & First quartile & 30 & 4.9 \\
\hline & Second & 72 & 11.7 \\
\hline & Third & 205 & 33.3 \\
\hline & Fourth & 148 & 24.1 \\
\hline & Fifth & 160 & 26 \\
\hline
\end{tabular}

fuel was firewood, animal dung, and crop residues. Among the respondents, $11.5 \%$ smoke cigarettes and $8.3 \%$ of them smoke more than three times per day. More than half of houses in the study did not have a window and $90 \%$ of them had no enclosed area/built 


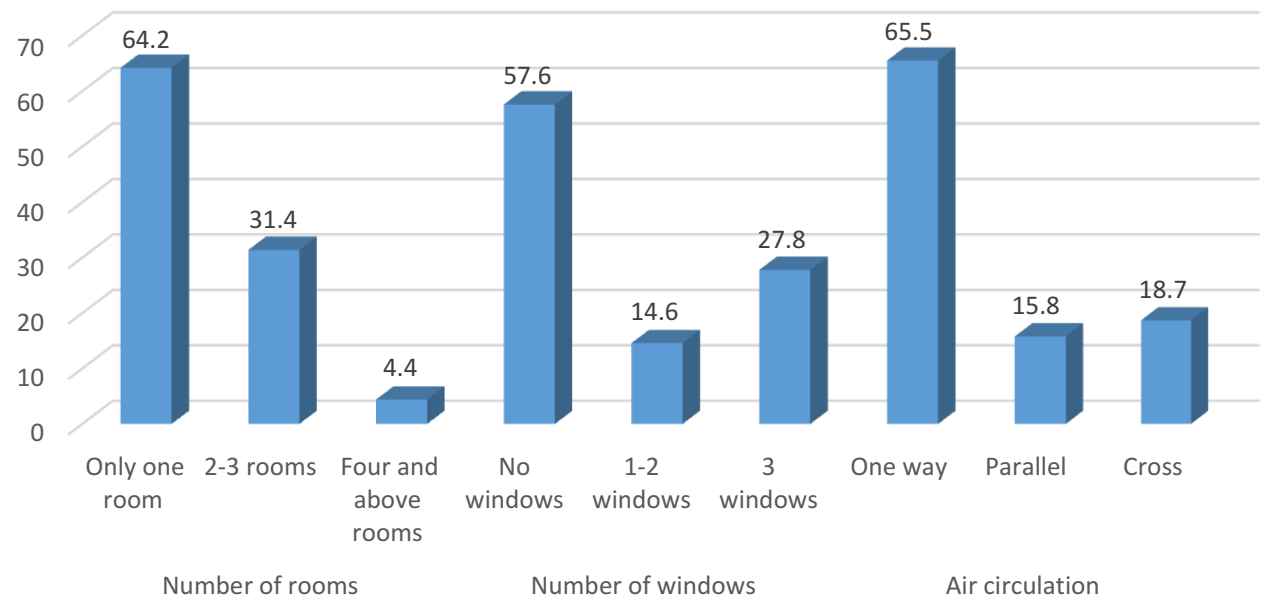

Figure I Major housing characteristics distribution in AM-HDSS, Southern Ethiopia, 2020.

structure for the kitchen. More than half of the houses, 58\% have separated kitchen while $42 \%$ houses $64.2 \%$ have only one room; the remaining have kitchen connected with main house or inside the $35.8 \%$ houses have more than two rooms. Among the house.

Table 2 The Mean Lung Function Parameters in Relation to Age and Sex Factors in AM-HDSS, Southern Ethiopia, 2020

\begin{tabular}{|c|c|c|c|c|c|c|c|c|}
\hline Lung Function Test Parameter & Sex & Mean Score & $P$-value & Mean & $P$-value & Age & Mean Score & $P$-value \\
\hline \multirow[t]{2}{*}{ FVC PREI } & Male & 2.78 & \multirow[t]{2}{*}{0.01} & 2.07 & \multirow[t]{2}{*}{0.047} & $\leq 40$ years & 2.61 & \multirow[t]{2}{*}{0.54} \\
\hline & Female & 2.05 & & 2.98 & & $\geq 41$ years & 2.30 & \\
\hline \multirow[t]{2}{*}{ FVC \% Pred } & Male & $81.77 \%$ & \multirow[t]{2}{*}{0.90} & $73.37 \%$ & \multirow[t]{2}{*}{0.147} & $\leq 40$ years & $75.44 \%$ & \multirow[t]{2}{*}{0.64} \\
\hline & Female & $80.14 \%$ & & $94.91 \%$ & & $\geq 41$ years & $82.92 \%$ & \\
\hline \multirow[t]{2}{*}{ FEV, PRE I } & Male & 2.21 & \multirow[t]{2}{*}{0.02} & 1.75 & \multirow[t]{2}{*}{0.069} & $\leq 40$ years & 2.32 & \multirow[t]{2}{*}{0.034} \\
\hline & Female & 1.66 & & 2.21 & & $\geq 41$ years & 1.75 & \\
\hline \multirow[t]{2}{*}{ FEV I\% Pred } & Male & $79.47 \%$ & \multirow[t]{2}{*}{0.71} & $72.56 \%$ & \multirow[t]{2}{*}{0.88} & $\leq 40$ years & $78.83 \%$ & \multirow[t]{2}{*}{0.88} \\
\hline & Female & $76.36 \%$ & & $87.52 \%$ & & $\geq 41$ years & $77.38 \%$ & \\
\hline \multirow[t]{2}{*}{ PEF PREI } & Male & 4.35 & \multirow[t]{2}{*}{0.026} & 3.45 & \multirow[t]{2}{*}{0.13} & $\leq 40$ years & 4.49 & \multirow[t]{2}{*}{0.878} \\
\hline & Female & 3.22 & & 4.26 & & $\geq 41$ years & 3.45 & \\
\hline \multirow[t]{2}{*}{ PEF \% Pred } & Male & $59.40 \%$ & \multirow[t]{2}{*}{0.63} & $55.98 \%$ & \multirow[t]{2}{*}{0.55} & $\leq 40$ years & $63.83 \%$ & \multirow[t]{2}{*}{0.067} \\
\hline & Female & $55.97 \%$ & & $60.43 \%$ & & $\geq 41$ years & $55.17 \%$ & \\
\hline \multirow[t]{2}{*}{ FEV/FVC PREI } & Male & 87.37 & \multirow[t]{2}{*}{0.475} & 85.76 & \multirow[t]{2}{*}{0.824} & $\leq 40$ years & 92.11 & \multirow[t]{2}{*}{0.27} \\
\hline & Female & 83.64 & & 84.54 & & $\geq 41$ years & 82.80 & \\
\hline \multirow[t]{2}{*}{ FEV/FVC \% Pred } & Male & $107.23 \%$ & \multirow[t]{2}{*}{0.244} & $104.49 \%$ & \multirow[t]{2}{*}{0.70} & $\leq 40$ years & $105.72 \%$ & \multirow[t]{2}{*}{0.66} \\
\hline & Female & $100.78 \%$ & & $102.26 \%$ & & $\geq 41$ years & $102.96 \%$ & \\
\hline \multirow[t]{2}{*}{ FEF25-75 PRE I } & Male & 2.58 & \multirow[t]{2}{*}{0.220} & 2.22 & 0.453 & $\leq 40$ years & 3.42 & 0.001 \\
\hline & Female & 2.12 & & 2.52 & & $\geq 41$ years & 1.92 & \\
\hline FEF $25-75 \%$ Pred & Male & $77.73 \%$ & 0.714 & $70.53 \%$ & 0.279 & $\leq 40$ years & $89.06 \%$ & 0.161 \\
\hline & Female & $73.28 \%$ & & $84.22 \%$ & & $\geq 4$ I years & $70.15 \%$ & \\
\hline
\end{tabular}

Abbreviations: $\mathrm{FVC}$, forced vital capacity; $\mathrm{FVC} \%$, percentage of the FVC expired in the first one second; $F E V_{1}$, forced expiratory volume in the first one second; PRE, predicted values. 


\section{Mean Lung Function Parameters in Relation Factors}

The lung function test parameters had lower mean score in females and in those who are in advanced age study participants. According to the test, $\mathrm{FEV}_{1} / \mathrm{PRE} 1$ is lower among females and greater than 41 year old participants (Table 2).

\section{Prevalence of Chronic Obstructive Pulmonary Disease}

Among study participants $10.6 \%$ had chronic obstructive pulmonary disease. Among the participants who have cough $60.3 \%$ had duration of chronic cough less than 4 years, $29.31 \%$ had $4-10$ years and rest had above 11 years. Of study participants who had chronic cough $62.1 \%$ had sputum and the rest $37.9 \%$ had dry cough. Coughing was worsens at night time which accounts for $32.76 \%$, while $23.28 \%$ their cough worsened in day time. Among study participants $6 \%$ of them had shortness of breath and half of them had two years duration of shortness of breath (Table 3 ).

\section{Chronic Obstructive Pulmonary Disease and Housing Conditions}

Relatively higher proportions of COPD cases existed in highland residence, which accounts for $63.8 \%$ compared to $36.2 \%$ lowland residence. In the case of housing type, $65.5 \%$ of COPD cases live in a traditional hut (tukulu). In addition, houses with no windows and one room had a relatively higher number of COPD cases compared to those which had windows and more than one room (Figure 2).

\section{Factors Affecting Chronic Obstructive Pulmonary Disease}

In binary logistic analysis factors like age $\geq 41$ years COR $2.82(1.65,4.83)$, living in highland area $1.71(1,2.92)$,

Table 3 Cough and its Characteristics Among Study Participants in AM-HDSS, Southern Ethiopia, 2020

\begin{tabular}{|c|c|c|c|}
\hline Variable & Category of Variable & Frequency & Percent \\
\hline Duration of cough & $\begin{array}{l}\text { No cough } \\
<4 \text { years } \\
4-10 \text { years } \\
\geq 11 \text { years }\end{array}$ & $\begin{array}{l}557 \\
35 \\
17 \\
6\end{array}$ & $\begin{array}{l}90.60 \\
5.70 \\
2.80 \\
1.00\end{array}$ \\
\hline Time of cough worsening time & $\begin{array}{l}\text { In the morning } \\
\text { In the day time } \\
\text { At night } \\
\text { At all time }\end{array}$ & $\begin{array}{l}22 \\
27 \\
38 \\
29\end{array}$ & $\begin{array}{l}18.97 \\
23.28 \\
32.76 \\
25.00\end{array}$ \\
\hline Factors worsen cough & $\begin{array}{l}\text { During cold weather } \\
\text { During hot temperature } \\
\text { During smoke exposure } \\
\text { During dust exposure } \\
\text { More than the above }\end{array}$ & $\begin{array}{l}56 \\
19 \\
16 \\
2 \\
35\end{array}$ & $\begin{array}{l}43.75 \\
14.84 \\
12.50 \\
1.56 \\
27.34\end{array}$ \\
\hline Type of sputum & $\begin{array}{l}\text { Dry cough } \\
\text { Have sputum }\end{array}$ & $\begin{array}{l}22 \\
36\end{array}$ & $\begin{array}{l}37.90 \\
62.10\end{array}$ \\
\hline Duration of sputum & $\begin{array}{l}<2 \text { years } \\
3-5 \text { years } \\
\geq 6 \text { years }\end{array}$ & $\begin{array}{l}29 \\
21 \\
8\end{array}$ & $\begin{array}{l}50.00 \\
36.20 \\
13.79\end{array}$ \\
\hline Time of sputum worsening & $\begin{array}{l}\text { In the morning } \\
\text { In the day time } \\
\text { At night } \\
\text { All the time }\end{array}$ & $\begin{array}{l}16 \\
24 \\
39 \\
31\end{array}$ & $\begin{array}{l}14.55 \\
21.82 \\
35.45 \\
28.18\end{array}$ \\
\hline Shortness of breath & $\begin{array}{l}\text { Yes } \\
\text { No }\end{array}$ & $\begin{array}{l}37 \\
578\end{array}$ & $\begin{array}{l}6.00 \\
94.00\end{array}$ \\
\hline Duration of shortness of breath & $\begin{array}{l}<2 \text { years } \\
3-5 \text { years } \\
\geq 6 \text { years }\end{array}$ & $\begin{array}{l}19 \\
11 \\
7\end{array}$ & $\begin{array}{l}51.35 \\
29.73 \\
18.92\end{array}$ \\
\hline
\end{tabular}




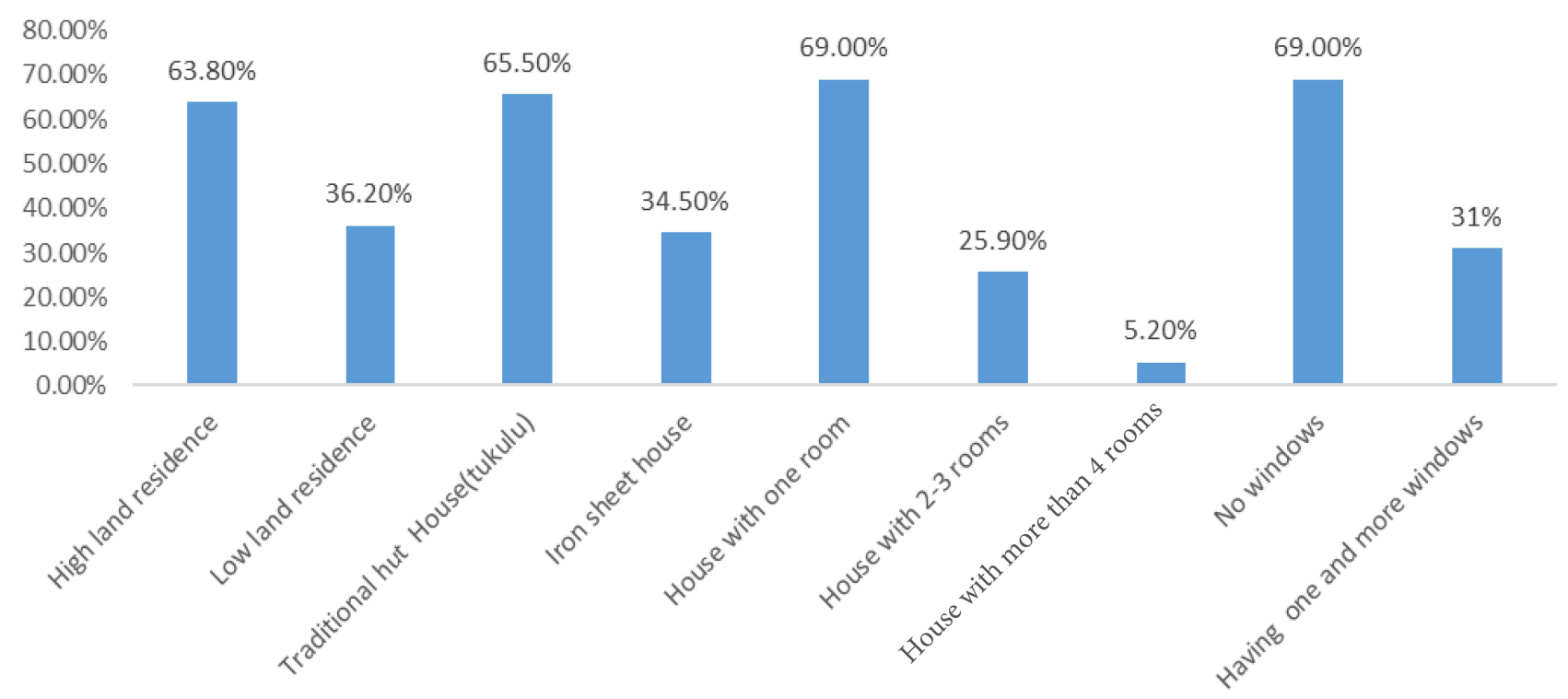

Figure 2 The relationship between housing condition and area of residence with COPD case, AM-HDSS, Southern Ethiopia, 2020.

those who are elementary education $2.45(1.13,5.28)$, those who shares the house with domestic animals COR $2.34(1.28,4.28)$ and having a house that had no windows COR $1.75(1.01,3.05)$ were associated with chronic obstructive pulmonary disease.

Variables which have association in binary logistic analysis which had a $P$-value $<0.3$ were candidates for multivariable analysis. Finally, multivariable logistic regression analysis indicated that age $\geq 41$ years AOR 3.65 (1.83, 7.28), living in highland area $1.71(1,2.92)$, those with elementary education level 2.45 (1.13, 5.28), who had no separate house for domestic animals AOR $2.84(1.38,5.85)$, having a house that had no windows AOR $3.05(5.79,1.12)$ and living in traditional hut (tukulu) AOR $5.92(1.19,29.42)$ were significantly associated with chronic obstructive pulmonary disease in the study area (Table 4).

\section{Discussion}

In this study, the prevalence of spirometry-defined chronic obstructive pulmonary disease was $10.6 \%$. This finding is comparable with previous studies conducted in Nepal $(8.5 \%)$ and China (8\%). ${ }^{13,14}$ The prevalence reported in this study is lower than the estimate from Ethiopia (17.8\%) and Uganda (16.2\%). ${ }^{9,12}$ The inconsistency in the prevalence estimates could be explained by the variation in the methods of estimation. This study defined COPD together with airflow obstruction and the presence of symptoms, while earlier studies defined COPD depending on airflow obstruction only and could be due to variations in study population, sample size, and differences in health-care systems.

Relatively the prevalence of COPD in participants who live in the highland area was $12.8 \%$ whereas it was $7.9 \%$ in the lowland area. This indicated that COPD is one of the chronic illnesses which cause respiratory morbidity in the study area especially in highland agro-ecology. This result is in line with a population-based observational study conducted in Kyrgyzstan and among pooled representative samples of adults in well-defined administrative areas worldwide. ${ }^{15,16}$ This may be due to the fact that the study participants who lived in a highland area utilized biomass fuel for long durations to heat the house. This biomass smoke exposure put the individuals at risk of developing COPD. ${ }^{17,18}$

The present study identified some factors which are strongly associated with COPD. Participants who are in advanced age $>41$ years (AOR $3.65 ; 1.83,7.28$ ) had more than 3.6 times developed COPD compared to those in the age range $<40$ years. This finding is consistent with the result of other studies, ${ }^{7}$ which reported that the frequency of COPD had a tendency to increase with age and old age is considered a risk factor for developing COPD. ${ }^{19,20}$ The effect of age with COPD may due more exposure to risk factors like biomass fuel, smoking and physiological decrease in respiratory function with age which begins around the age of 30-40 years. $^{9,18}$ Study participants who had domestic 
Table 4 Factors Associated with COPD AM-HDSSS, Southern Ethiopia, 2020

\begin{tabular}{|c|c|c|c|c|c|c|}
\hline \multicolumn{2}{|l|}{ List of Factors } & \multicolumn{2}{|c|}{ COPD Status } & \multirow{2}{*}{$\begin{array}{l}\text { COR with 95\% } \\
\text { Cl (Lower, } \\
\text { Upper) }\end{array}$} & \multirow{2}{*}{$\begin{array}{l}\text { AOR with 95\%CI } \\
\text { (Lower, Upper) }\end{array}$} & \multirow[t]{2}{*}{$P$-value } \\
\hline Variable & Category of Variable & YesN (\%) & NoN (\%) & & & \\
\hline Sex & $\begin{array}{l}\text { Male } \\
\text { Female }\end{array}$ & $\begin{array}{l}33(5.4) \\
32(5.2)\end{array}$ & $\begin{array}{l}298(48.4) \\
252(4 I)\end{array}$ & $\begin{array}{l}1.00 \\
1.15(0.69,1.92)\end{array}$ & $\begin{array}{l}1.00 \\
1.22(0.63,2.37)\end{array}$ & 0.56 \\
\hline Wealth index & $\begin{array}{l}\text { Poor } \\
\text { Medium } \\
\text { Rich }\end{array}$ & $\begin{array}{l}6(5.9) \\
28(13.7) \\
31(10.1)\end{array}$ & $\begin{array}{l}96(94.1) \\
177(86.3) \\
277(89.9)\end{array}$ & $\begin{array}{l}1.79(0.73,4.42) \\
0.71(0.41,1.22) \\
1.00\end{array}$ & $\begin{array}{l}1.56(0.6,4.08) \\
0.91(0.49,1.66) \\
1.00\end{array}$ & $\begin{array}{l}0.36 \\
0.75\end{array}$ \\
\hline Age & $\begin{array}{l}<40 \text { years } \\
>41 \text { Years }\end{array}$ & $\begin{array}{l}23(6.4) \\
42(16.3)\end{array}$ & $\begin{array}{l}334(93.6) \\
216(83.7)\end{array}$ & $\begin{array}{l}1.00 \\
2.82(1.65,4.83)\end{array}$ & $\begin{array}{l}1.00 \\
3.65(1.83,7.28)\end{array}$ & $0.001 *$ \\
\hline Residence area & $\begin{array}{l}\text { Highland } \\
\text { Lowland }\end{array}$ & $\begin{array}{l}42(12.9) \\
23(8.0)\end{array}$ & $\begin{array}{l}284(87.1) \\
266(92.0)\end{array}$ & $\begin{array}{l}1.71(1,2.92) \\
1.00\end{array}$ & $\begin{array}{l}1.15(0.42,3.14) \\
1.00\end{array}$ & 0.79 \\
\hline Education level & $\begin{array}{l}\text { No formal education } \\
\text { Elementary } \\
\text { Secondary and above }\end{array}$ & $\begin{array}{l}53(12.7) \\
4(7.0) \\
8(5.6)\end{array}$ & $\begin{array}{l}363(87.3) \\
53(93.0) \\
134(94.4)\end{array}$ & $\begin{array}{l}1.94(0.67,5.56) \\
2.45(1.13,5.28) \\
1.00\end{array}$ & $\begin{array}{l}0.57(0.22,1.46) \\
0.79(0.21,2.92) \\
1.00\end{array}$ & $\begin{array}{l}0.24 \\
0.72\end{array}$ \\
\hline Occupation & $\begin{array}{l}\text { Farmer } \\
\text { Housewife } \\
\text { Government and Private } \\
\text { business }\end{array}$ & $\begin{array}{l}43(10.3) \\
13(13.7) \\
9(87.4)\end{array}$ & $\begin{array}{l}374(89.7) \\
82(86.3) \\
94(12.6)\end{array}$ & $\begin{array}{l}0.83(0.39,1.77) \\
0.60(0.25, I .49) \\
1.00\end{array}$ & $\begin{array}{l}1.53(0.63,3.75) \\
1.25(0.36,4.29) \\
1.00\end{array}$ & $\begin{array}{l}0.35 \\
0.72\end{array}$ \\
\hline $\begin{array}{l}\text { Having domestic } \\
\text { animals }\end{array}$ & $\begin{array}{l}\text { Had no domestic animal } \\
\text { Had separated house } \\
\text { Had no separated house }\end{array}$ & $\begin{array}{l}13(7.7) \\
18(7.6) \\
34(16.2)\end{array}$ & $\begin{array}{l}156(92.3) \\
218(92.4) \\
176(83.8)\end{array}$ & $\begin{array}{l}1.00 \\
2.32(1.18,4.55) \\
2.34(1.28,4.28)\end{array}$ & $\begin{array}{l}1.00 \\
2.61(1.21,5.64) \\
2.84(1.38,5.85)\end{array}$ & $\begin{array}{l}0.01 * \\
0.00 I^{*}\end{array}$ \\
\hline $\begin{array}{l}\text { Duration biomass } \\
\text { fuel exposure }\end{array}$ & $\begin{array}{l}\text { Use }<40 \text { years } \\
\text { Use above }>41 \text { years }\end{array}$ & $\begin{array}{l}43(9.1) \\
22(15.4)\end{array}$ & $\begin{array}{l}429(90.9) \\
12184.6)\end{array}$ & $\begin{array}{l}1.00 \\
1.81(1.04,3.15)\end{array}$ & $\begin{array}{l}1.00 \\
0.87(0.42,1.81)\end{array}$ & 0.72 \\
\hline $\begin{array}{l}\text { Frequent } \\
\text { cigarette and gaya } \\
\text { smoking }\end{array}$ & $\begin{array}{l}\text { Yes } \\
\text { No }\end{array}$ & $\begin{array}{l}9(12.7) \\
56(10.3)\end{array}$ & $\begin{array}{l}62(87.3) \\
488(89.7)\end{array}$ & $\begin{array}{l}1.26(0.6,2.68) \\
1.00\end{array}$ & $\begin{array}{l}0.9(0.4,2.02) \\
1.00\end{array}$ & 0.8 \\
\hline Having windows & $\begin{array}{l}\text { Had no windows } \\
\text { Had windows }\end{array}$ & $\begin{array}{l}45(12.7) \\
20(7.7)\end{array}$ & $\begin{array}{l}309(87.3) \\
24 I(92.3)\end{array}$ & $\begin{array}{l}1.75(1.01,3.05) \\
1.00\end{array}$ & $\begin{array}{l}5.79(1.12,29.99) \\
1.00\end{array}$ & $0.04 *$ \\
\hline Use of kitchen & $\begin{array}{l}\text { Open fire } \\
\text { Without air ventilation } \\
\text { With air ventilation }\end{array}$ & $\begin{array}{l}26(8.0) \\
25(15.1) \\
14(11.2)\end{array}$ & $\begin{array}{l}298(92.0) \\
|4|(84.9) \\
|| \mid(88.8)\end{array}$ & $\begin{array}{l}0.49(0.27,0.88 \\
0.69(0.35,1.37) \\
1.00\end{array}$ & $\begin{array}{l}1.95(0.88,4.35) \\
0.98(0.44,2.21) \\
1.00\end{array}$ & $\begin{array}{l}0.1 \\
0.97\end{array}$ \\
\hline Type of house & $\begin{array}{l}\text { Made from iron sheets } \\
\text { Traditional hut }\end{array}$ & $\begin{array}{l}22(8.7) \\
43(11.9)\end{array}$ & $\begin{array}{l}232(91.3) \\
318(88.1)\end{array}$ & $\begin{array}{l}1.00 \\
1.42(0.83,2.45)\end{array}$ & $\begin{array}{l}1.00 \\
5.92(1.19,29.42)\end{array}$ & $0.03 *$ \\
\hline
\end{tabular}

Note: *Significant factors.

Abbreviations: $C O R$, crude odd ratio; $A O R$, adjusted odd ratio; $\mathrm{Cl}$, confidence interval; $\mathrm{COPD}$, chronic obstructive pulmonary disease.

animals and lack separate housing conditions (AOR 2.84) more likely developed COPD compared to those who had no domestic animals (AOR 1.38, 5.85). This effect is due to animal dung utilization for household food preparation and associated exposure to smoke and this leads to lung irritation and subsequently development of COPD. ${ }^{9,21}$
Residence who live in a highland area had (AOR $1.71 ; 1,2.92) 1.7$ times more likely developed COPD compared to those who live in a lowland area. This is due to the fact that study participants who live in a highland area almost all live in traditional huts and this housing type lacks windows for air circulation. As indicated in this study, participants who lived in 
traditional huts (tukulu) and who lack windows had significant contributing factors for development of COPD. The housing environment influences the physical and mental health of the inhabitants. Poor ventilation may increase exposure to smoke, which can lead to COPD. Indoor exposure to nitrogen dioxide (from poorly functioning combustion appliances) is the major factor affecting COPD. ${ }^{17,18}$

\section{Conclusion and Recommendation}

Chronic obstructive pulmonary disease (COPD) was one of the public health preventive respiratory illness in people who live in highland and traditional house who lack windows for air circulation. The identified contributing factors for COPD are modifiable factors such as lack of windows, those sharing houses with domestic animals and living in traditional huts (tukulu) and un-modifiable factor such as advanced age was also a significant contributing factor in the study area.

Therefore, improving housing condition of traditional huts by constructing windows for air circulation should be taken as a public health measure. In addition constructing separate a house for domestic animals and minimizing animal dung smoke exposure by improving air circulation in the house is mandatory to reduce respiratory illness. Due attention for individuals who are in advanced age should be given to avoid household smoke exposure.

\section{Acknowledgments}

The authors are grateful to Arba Minch University for providing this opportunity to conduct the research. We thank study participants for their genuine responses and participation.

\section{Disclosure}

The authors report no conflicts of interest in this work.

\section{References}

1. Lozano R, Naghavi M, Foreman K, et al. Global and regional mortality from 235 causes of death for 20 age groups in 1990 and 2010: a systematic analysis for the Global Burden of Disease Study 2010. Lancet. 2012;380(9859):2095-2128. doi:10.1016/S0140-6736(12) 61728-0

2. Buist A, McBurnie M, Vollmer $\mathrm{W}$, et al. International variation in the prevalence of COPD (the BOLD study): a population-based prevalence study. Lancet. 2007;370(9589):741-750. doi:10.1016/S01406736(07)61377-4

3. Rabe KF, Hurd S, Anzueto A, et al. Global initiative for chronic obstructive lung disease. Global strategy for the diagnosis, management, and prevention of chronic obstructive pulmonary disease: GOLD executive summary. Am J Respir Crit Care Med. 2007;176 (6):532-555. doi:10.1164/rccm.200703-456SO.
4. Ignatiev V, Titov O, Gultyaeva O. Chronic Obstructive Pulmonary Disease: Epidemiology and Economic Damage. Bulletin of St. Petersburg University; 2007:37-46.

5. Cruz AA. Global Surveillance, Prevention and Control of Chronic Respiratory Diseases: A Comprehensive Approach. World Health Organization; 2007.

6. Kurmi OP, Lam KBH, Ayres JG. Indoor air pollution and the lung in low-and medium-income countries. Eur Respiratory Soc. 2012;40 (1):239-254. doi:10.1183/09031936.00190211

7. Musafiri S, van Meerbeeck J, Musango L, et al. Prevalence of atopy, asthma and COPD in an urban and a rural area of an African country. Respir Med. 2011;105(11):1596-1605. doi:10.1016/j.rmed.2011.06.013

8. Van Schayck C, Chavannes N. Detection of asthma and chronic obstructive pulmonary disease in primary care. Eur Respir J. 2003;21(39 suppl):16s-22s. doi:10.1183/09031936.03.00040403

9. Woldeamanuel GG, Mingude AB, Geta TG. Prevalence of chronic obstructive pulmonary disease (COPD) and its associated factors among adults in Abeshge District, Ethiopia: a cross sectional study. BMC Pulm Med. 2019;19(1):1-9. doi:10.1186/s12890-019-0946-z

10. Polatli M, Ben Kheder A, Wali S, et al. Chronic obstructive pulmonary disease and associated healthcare resource consumption in the Middle East and North Africa: the BREATHE study. Respir Med. 2012;106:S75-S85. doi:10.1016/S0954-6111(12)70016-1

11. Salvi S, Barnes PJ. Is exposure to biomass smoke the biggest risk factor for COPD globally? Chest. 2010;138(1):3-6. doi:10.1378/ chest.10-0645

12. Van Gemert F, Kirenga B, Chavannes N, et al. Prevalence of chronic obstructive pulmonary disease and associated risk factors in Uganda (FRESH AIR Uganda): a prospective cross-sectional observational study. Lancet Glob Health. 2015;3:e44-51. doi:10.1016/S2214-109X (14)70337-7

13. Adhikari TB, Acharya P, Högman M, et al. Prevalence of chronic obstructive pulmonary disease and its associated factors in Nepal: findings from a community-based household survey. Int $J$ Chron Obstruct Pulmon Dis. 2020;15:2319-2331. doi:10.2147/COPD. S268110

14. Zhong N, Wang C, Yao W, et al. Prevalence of chronic obstructive pulmonary disease in China: a large, population-based survey. Am $J$ Respir Crit Care Med. 2007;176(8):753-760. doi:10.1164/ rccm.200612-1749OC.

15. Brakema EA, Tabyshova A, Kasteleyn MJ, et al. High COPD prevalence at high altitude: does household air pollution play a role? Eur Respir J. 2019;53:1801193. doi:10.1183/13993003.01193-2018

16. Horner A, Soriano JB, Puhan MA, et al. Altitude and COPD prevalence: analysis of the PREPOCOL-PLATINO-BOLD-EPI-SCAN study. Respir Res. 2017;18:162. doi:10.1186/s12931-017-0643-5

17. Kanchongkittiphon W, Mendell MJ, Gaffin JM, Wang G, Phipatanakul W. Indoor environmental exposures and exacerbation of asthma: an update to the 2000 review by the Institute of Medicine. Environ Health Perspect. 2015;123(1):6-20. doi:10.1289/ehp.13 07922

18. Nugmanova D, Sokolova L, Feshchenko Y, et al. The prevalence, burden and risk factors associated with bronchial asthma in commonwealth of independent states countries (Ukraine, Kazakhstan and Azerbaijan): results of the CORE study. BMC Pulm Med. 2018;18 (1):110. doi:10.1186/s12890-018-0676-7

19. Sutradhar I, Das Gupta R, Hasan M, Wazib A, Sarker M. Prevalence and risk factors of chronic obstructive pulmonary disease in Bangladesh: a systematic review. Cureus. 2019;11(1):e3970. doi:10. 7759/cureus.3970

20. Mannino DM, Buist AS. Global burden of COPD: risk factors, prevalence, and future trends. Lancet. 2007;370(9589):765-773. doi:10.1016/S0140-6736(07)61380-4

21. Behera D, Jindal SK. Respiratory symptoms in Indian women using domestic cooking fuels. Chest. 1991;100(2):385-388. doi:10.1378/ chest.100.2.385 


\section{Publish your work in this journal}

The International Journal of COPD is an international, peer-reviewed journal of therapeutics and pharmacology focusing on concise rapid reporting of clinical studies and reviews in COPD. Special focus is given to the pathophysiological processes underlying the disease, intervention programs, patient focused education, and self management protocols. This journal is indexed on PubMed Central, MedLine and CAS. The manuscript management system is completely online and includes a very quick and fair peer-review system, which is all easy to use. Visit http://www.dovepress.com/testimonials.php to read real quotes from published authors. 